\title{
Fungal diversity in the rhizosphere of endemic plant species of Tenerife (Canary Islands): relationship to vegetation zones and environmental factors
}

\author{
Christin Zachow ${ }^{1}$, Christian Berg ${ }^{2}$, Henry Müller ${ }^{1}$, Remo Meincke ${ }^{1}$,
} Monika Komon-Zelazowska ${ }^{3}$, Irina S Druzhinina ${ }^{3}$, Christian P Kubicek ${ }^{3}$ and Gabriele Berg ${ }^{1}$ ${ }^{1}$ Institute of Environmental Biotechnology, Graz University of Technology, Graz, Austria; ${ }^{2}$ Institute of Plant Sciences, Karl-Franzens-University of Graz, Graz, Austria and ${ }^{3}$ Institute of Chemical Engineering, Research Area Gene Technology and Applied Biochemistry, Vienna University of Technology, Vienna, Austria

\begin{abstract}
Knowledge about fungal diversity scaling relationships relative to that of plants is important to understand ecosystem functioning. Tenerife Island, a natural laboratory to study terrestrial biodiversity, is represented by six different vegetation zones characterized by specific abiotic conditions and plant communities with a high proportion of endemic plants. Little is known about the biodiversity of associated fungi. To understand the relationship between plant and fungal communities, we analysed soil/rhizosphere fungi from all vegetation zones. From 12 sampling points dispersed on the whole island, molecular analysis of fungal communities was determined by single-strand conformation polymorphism (SSCP) analysis using universal and specific primers for Trichoderma. The highly diverse fungal communities were mainly characterized by ectomycorrhizaforming Basidiomycota and a high proportion of yet-unidentified species. Besides, Trichodermaspecific SSCP resulted in low diversity of mainly cosmopolitan species, for example Hypocrea lixii/ $T$. harzianum. The dominance of $T$. harzianum was confirmed by cultivation. All Trichoderma isolates show an extraordinarily high antagonistic potential towards different groups of plant pathogens, supporting the hypothesis of extensive colonization by highly competitive Trichoderma species from the continent. In contrast, biodiversity patterns of the whole fungal and plant communities follow the same ecological rules. Furthermore, a high statistical correlation between fungal communities and the main environmental factors, temperature and precipitation, was found. The ISME Journal (2009) 3, 79-92; doi:10.1038/ismej.2008.87; published online 2 October 2008
\end{abstract}

Subject Category: Microbial population and community ecology

Keywords: fungal community; Trichoderma; plant-microbe interaction; antagonist

Macaronesia (Canary Islands, Madeira, Azores and Cape Verde Islands) has been recognized for a long time as a natural laboratory for model studies of diversification and development of terrestrial biodiversity (Emerson, 2002). In this study, we focused on Tenerife Island, with $2058 \mathrm{~km}^{2}$, the largest of the Canary archipelago. Its altitudinal profile is remarkable: the island has a triangle-based pyramid circumference with a truncated apex at $2000 \mathrm{~m}$ a.s.l. at Las Caňadas and is surmounted by the summit of Teide $(3718 \mathrm{~m})$. The island is of vulcanic origin, with an estimated age of more than 7 million years.

Correspondence: G Berg, Institute of Environmental Biotechnology, Graz University of Technology, Petersgasse 12, Graz A-8010, Austria.

E-mail: Gabriele.Berg@TUGraz.at

Received 23 May 2008; revised 12 August 2008; accepted 16 August 2008; published online 2 October 2008
Tenerife has a well-investigated flora: the endemics represent approximately $40 \%$ of the native flora, though $20 \%$ are meanwhile in the endangered category of the International Union for Conservation of Nature (Francisco-Ortega et al., 2000). Adaptive radiation into diverse habitats and genetic drift are often considered to be important factors producing such an extensive speciation (Baldwin et al., 1998). On Tenerife Island, plants form six clearly differentiated vegetation belts of one plant community each, which were originally described by Humboldt and Bonplandt (1814). These vegetation zones strongly correlate with abiotic parameters such as temperature in summer and winter, altitude, wind and sun exposure, allocation of precipitation during the year, occurrence of fog and frost and soil quality. Although studies of animal and plant communities resulted recently in highly interesting results about evolution and diversity of species 
(Emerson, 2002; Green and Bohannan, 2006), nothing is known about the microflora of Tenerife Island and their relationship to vegetation zones and abiotic parameters.

Fungi play an important role in terrestrial ecosystems especially in the rhizosphere, where they mediate many ecological processes, and are influential for plant growth and soil health. The diversity of soil- and rhizosphere-inhabiting fungi is much higher than previously thought (Vandenkoornhuyse et al., 2002; Gams, 2007). Molecular tools were developed to analyse the structure of terrestrial fungal communities (Kowalchuk, 1999; Vainio and Hantula, 2000; Anderson and Cairney, 2004; Berg et al., 2005), but little is known about their diversity, biogeography and ecology, especially in native ecosystems. Furthermore, microorganisms comprise much of the Earth's biodiversity, but our knowledge about their biodiversity scaling relationships relative to that of plants and animals is limited (Green and Bohannan, 2006). There is a close link between plant species and microbial community structure in the rhizosphere, and the hypothesis is that bacteria and fungi have also developed a unique diversity pattern over time, which may give insights into microbial evolution.

The objective of this work was to analyse the associated fungal communities of six different vegetation zones in Tenerife. Microfungi were isolated from 12 different sampling points and analysed by a multiphasic approach to analyse the relationships between the plant community, the associated fungal communities and abiotic parameters. Particular interest was laid on the analysis of members of the genus Trichoderma, a fungal genus that is often a predominant component of soil microflora and plays a key role in soil health (Harman et al., 2004; Berg et al., 2005; Migheli et al., 2008).

\section{Materials and methods}

Experimental design and ecological characterization of sampling points

Sampling was organized to cover all six main vegetation zones throughout Tenerife Island twice (Figure 1). Data about the vegetation zones and sampling points are shown in Table 1 . To select a sampling point, we search for a typical appearance of vegetation and a high level of hemeroby within each vegetation zone. The second sampling point should be distant as much as possible from the first. The abiotic differences in the six vegetation zones are extraordinarily high within a comparable little territory. The main abiotic parameters such as allocation of temperature and precipitation during the year, altitude, exposure, fog and soil quality can easily be summarized in the two most important climatic factors, annual temperature and precipitation. These data were measured for a long time on Tenerife Islands; in Table 1, they are summarized from Huetz de Lemps (1969), Kämmer (1974) and Fernandopullé (1976). Furthermore, soil types on

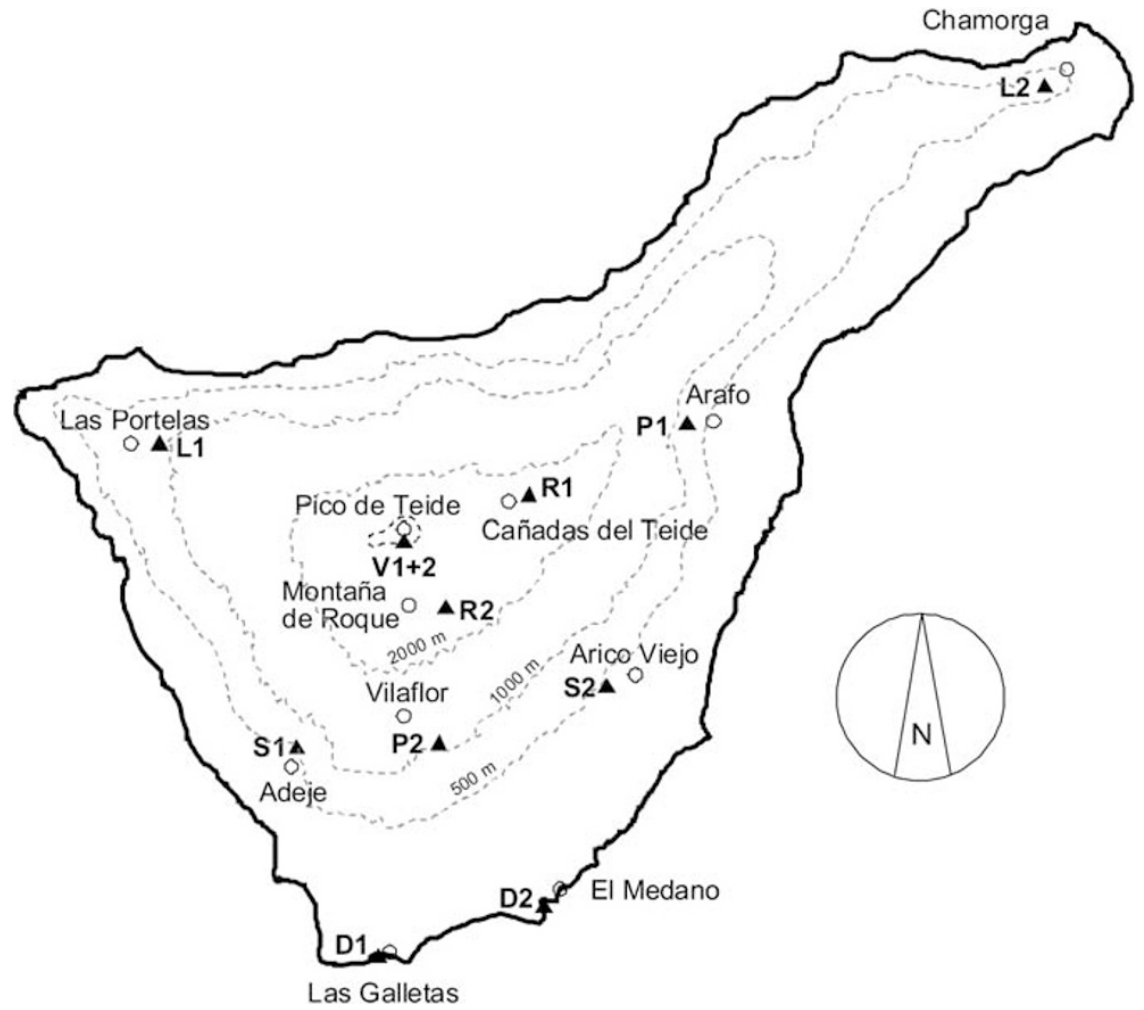

Figure 1 Tenerife Island map with some orientation settlements (circles) and location of sampling points (triangles). 
Table 1 Location, altitude and vegetation of the sampling points, Tenerife Island, February 2007

\begin{tabular}{|c|c|c|c|c|c|c|c|c|}
\hline \multirow[t]{2}{*}{$A b b$. } & \multirow[t]{2}{*}{ Date } & \multirow[t]{2}{*}{ Location } & \multirow[t]{2}{*}{ Coordinates } & \multirow[t]{2}{*}{$A l t^{\mathrm{a}}$} & \multicolumn{2}{|r|}{ Sampling grid } & \multicolumn{2}{|c|}{$\begin{array}{c}\text { Climatic } \\
\text { characteristics }\end{array}$} \\
\hline & & & & & Classification & Vascular plants ${ }^{\mathrm{b}}$ & ${ }^{\circ} C^{\mathrm{c}}$ & $m m^{\mathrm{d}}$ \\
\hline D1 & 06-02-2007 & $\begin{array}{l}1.5 \mathrm{~km} \mathrm{~W} \\
\text { Las Galletas }\end{array}$ & $\begin{array}{l}28^{\circ} 00^{\prime} 27^{\prime \prime} \mathrm{N} \\
16^{\circ} 39^{\prime} 59^{\prime \prime} \mathrm{W}\end{array}$ & $1 \mathrm{~m}$ & $\begin{array}{l}\text { Desert and coastal dune vegetation: } \\
\text { Zygophyllum-Zollikoferia semidesert } \\
\text { (subtropical, arid) }\end{array}$ & $\begin{array}{l}\text { Argyranthemum frutescens } s^{\mathrm{e}} \text {, Launeaea arborescens, } \\
\text { Fagonia cretica, Schizogyne serriata }\end{array}$ & 23.5 & 100 \\
\hline D2 & $06-02-2007$ & $\begin{array}{l}1.0 \mathrm{~km} \mathrm{SW} \\
\text { El Medano }\end{array}$ & $\begin{array}{l}28^{\circ} 02^{\prime} 22^{\prime \prime} \mathrm{N} \\
16^{\circ} 32^{\prime} 38^{\prime \prime} \mathrm{W}\end{array}$ & $2 \mathrm{~m}$ & & $\begin{array}{l}\text { Atriplex glauca var. Ifniensis, Launeaea arborescens, } \\
\text { Lotus sessilifolius }^{\mathrm{e}} \text {, Polycarpaea nivea, Schizogyne } \text { serriata }^{\mathrm{e}}\end{array}$ & & \\
\hline S1 & 06-02-2007 & $\begin{array}{l}1.2 \mathrm{~km} \\
\text { NE Adeje }\end{array}$ & $\begin{array}{l}28^{\circ} 07^{\prime} 53^{\prime \prime} \mathrm{N} \\
16^{\circ} 43^{\prime} 08^{\prime \prime} \mathrm{W}\end{array}$ & $480 \mathrm{~m}$ & $\begin{array}{l}\text { Succulent zone (Cardonal/Tanaibal): } \\
\text { Kleinio nerifolii-Euphorbietea } \\
\text { canariensis (subtropical, arid) }\end{array}$ & $\begin{array}{l}\text { Asphodelus aesitivus, Euphorbia regis-jubae }{ }^{\mathrm{e}} \\
\text { Hyparrhenia hirta, Kleinia neriifolia } \text { Lavendula canariensis }^{\mathrm{e}} \text {, } \\
\text { Opuntia dillenii, Plocama pendula }^{\mathrm{e}} \text {,Taekolmia pinnata }\end{array}$ & 18.5 & 250 \\
\hline S2 & 09-02-2007 & $\begin{array}{l}2.5 \mathrm{~km} \mathrm{SW} \\
\text { Arico Viejo }\end{array}$ & $\begin{array}{l}28^{\circ} 10^{\prime} 13^{\prime \prime} \mathrm{N} \\
16^{\circ} 30^{\prime} 07^{\prime \prime} \mathrm{W}\end{array}$ & $510 \mathrm{~m}$ & & $\begin{array}{l}\text { Aeonium cf. urbicum }{ }^{\mathrm{e}} \text {, Anagallis arvensis, Asparagus } \\
\text { pastorianus }^{\mathrm{e}}, \text { Euphorbia regis-jubae }{ }^{\mathrm{e}}, \text { Hyparrhenia hirta, } \\
\text { Kleinia neriifolia }^{\mathrm{e}} \\
\text { Lavendula canariensis }^{\mathrm{e}}, \text { Periploca laevigata, Taekolmia } \\
\text { pinnata }^{\mathrm{e}}\end{array}$ & & \\
\hline L1 & 10-02-2007 & $\begin{array}{l}0.9 \mathrm{~km} \mathrm{E} \\
\text { Las Portelas }\end{array}$ & $\begin{array}{l}28^{\circ} 19^{\prime} 43^{\prime \prime} \mathrm{N} \\
16^{\circ} 49^{\prime} 59^{\prime \prime} \mathrm{W}\end{array}$ & $950 \mathrm{~m}$ & $\begin{array}{l}\text { Laurel wood (Laurisilva/Fayal-Brezal): } \\
\text { Pruno hixae-Lauretea azoricae } \\
\text { (subtropical, subhumid) }\end{array}$ & $\begin{array}{l}\text { Asplenium onopteris, Dryopteris oligodonta }{ }^{\mathrm{e}}, \text { Ilex }_{\text {canariensis }}{ }^{\mathrm{e}} \text {, } \\
\text { Laurus azoricus }^{\mathrm{e}} \text {, Picconia excelsior } \\
\text { Ranunculus cortusifolius }^{\mathrm{e}}\end{array}$ & 12.5 & 650 \\
\hline L2 & $12-02-2007$ & $\begin{array}{l}1.5 \mathrm{~km} \text { SW } \\
\text { Chamorga }\end{array}$ & $\begin{array}{l}28^{\circ} 33^{\prime} 34^{\prime \prime} \mathrm{N} \\
16^{\circ} 10^{\prime} 08^{\prime \prime} \mathrm{W}\end{array}$ & $800 \mathrm{~m}$ & & Dryopteris oligodonta ${ }^{\mathrm{e}}$, Laurus azoricus ${ }^{\mathrm{e}}$, Prunus lusitanica & & \\
\hline P1 & 09-02-2007 & $2.4 \mathrm{~km}$ W Arafo & $\begin{array}{l}28^{\circ} 20^{\prime} 24^{\prime \prime} \mathrm{N} \\
16^{\circ} 26^{\prime} 36^{\prime \prime} \mathrm{W}\end{array}$ & $990 \mathrm{~m}$ & $\begin{array}{l}\text { Canary pine forest (Pinar): Cytiso } \\
\text { proliferi-Pinetea canariensis } \\
\text { (warm tempered, semiarid) }\end{array}$ & $\begin{array}{l}\text { Cistus monspeliensis, Cistus symphytifolius }{ }^{\mathrm{e}} \text {, } \\
\text { Pinus canariensis }^{\mathrm{e}}\end{array}$ & 15.0 & 400 \\
\hline $\mathrm{P} 2$ & 09-02-2007 & $\begin{array}{l}3.7 \mathrm{~km} \mathrm{SE} \\
\text { Vilaflor }\end{array}$ & $\begin{array}{l}28^{\circ} 07^{\prime} 56^{\prime \prime} \mathrm{N} \\
16^{\circ} 36^{\prime} 52^{\prime \prime} \mathrm{W}\end{array}$ & $990 \mathrm{~m}$ & & $\begin{array}{l}\text { Cistus monspeliensis Cistus symphytifolius }{ }^{\mathrm{e}} \text {, } \\
\text { Pinus canariensis }^{\mathrm{e}}\end{array}$ & & \\
\hline R1 & 08-02-2007 & $\begin{array}{l}1.5 \mathrm{~km} \mathrm{NE} \\
\text { Las Cañadas } \\
\text { del Teide }\end{array}$ & $\begin{array}{l}28^{\circ} 18^{\prime} 07^{\prime \prime} \mathrm{N} \\
16^{\circ} 33^{\prime} 49^{\prime \prime} \mathrm{W}\end{array}$ & $2100 \mathrm{~m}$ & $\begin{array}{l}\text { Mountainous heath land } \\
\text { (Retamar-Codesar): Spartocytisetea } \\
\text { (tempered, arid, subalpine) }\end{array}$ & $\begin{array}{l}\text { Descurainia bourgaeana }{ }^{\mathrm{e}} \text {, Pterocephalus lasiospermus }{ }^{\mathrm{e}} \text {, } \\
\text { Spartocytisus supranubius } \mathrm{s}^{\mathrm{e}}\end{array}$ & 8.8 & 345 \\
\hline R2 & 08-02-2007 & $\begin{array}{l}1 \text { km E Montaña } \\
\text { de Roque }\end{array}$ & $\begin{array}{l}28^{\circ} 13^{\prime} 20^{\prime \prime} \mathrm{N} \\
16^{\circ} 37^{\prime} 10^{\prime \prime} \mathrm{W}\end{array}$ & $2200 \mathrm{~m}$ & & Pterocephalus lasiospermus ${ }^{\mathrm{e}}$, Spartocytisus supranubius ${ }^{\mathrm{e}}$ & & \\
\hline V1 & $13-02-2007$ & Pico de Teide & $\begin{array}{l}28^{\circ} 16^{\prime} 12^{\prime \prime} \mathrm{N} \\
16^{\circ} 38^{\prime} 19^{\prime \prime} \mathrm{W}\end{array}$ & $3480 \mathrm{~m}$ & $\begin{array}{l}\text { Lava rock alpine desert (Violeta): } \\
\text { Violetea cheiranthifoliae (tempered, } \\
\text { arid, alpine) }\end{array}$ & No vascular plants & 7.5 & 350 \\
\hline V2 & 13-02-2007 & Pico de Teide & $\begin{array}{l}28^{\circ} 16^{\prime} 11^{\prime \prime} \mathrm{N} \\
16^{\circ} 38^{\prime} 20^{\prime \prime} \mathrm{W}\end{array}$ & $3480 \mathrm{~m}$ & & No vascular plants & & \\
\hline
\end{tabular}

${ }^{\mathrm{a} A l t}=$ altitude above see level.

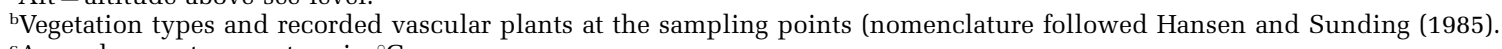

Annual mean temperature in ${ }^{\circ} \mathrm{C}$

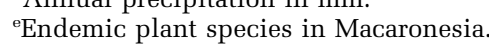


Tenerife Island are well studied. Different soil types have been produced due to the effects of vegetation, local weather conditions and topography on the basis of volcanic materials (Fernández Caldas et al., 1987; Hernández-Moreno et al., 2007). At the area of $1 \mathrm{~m}^{2}$ of each sampling point, the composition of vascular plants was analysed and the altitudes above see level were measured.

\section{Sampling}

Soil/rhizosphere was sampled from each sampling point in February in 2007. At each sampling point, four independent samples were taken in the corners of a $1 \mathrm{~m}^{2}$. We collected about $2 \mathrm{ml}$ of soil from a depth of approximately $10 \mathrm{~cm}$. Samples were placed into sterile Eppendorf tubes and transported to the laboratory.

Analysis of the community structure by single-strand conformation polymorphism analysis and

identification of bands

Microorganisms of the soil communities were extracted by mechanical disruption and homogenization of $400 \mu \mathrm{g}$ soil in a FastPrep Instrument (Qbiogene, BIO101 Systems, Carlsbad, CA, USA) for $30 \mathrm{~s}$ at a speed $5.0 \mathrm{~m} \mathrm{~s}^{-1}$. DNA was purified by the GeneClean Turbo Kit (Qbiogene, BIO101 Systems) containing the special binding buffer guanidine thiocyanate for the removal of humic acids. Extracted DNA $(8 \mu \mathrm{l})$ was treated with RNase $(2 \mu \mathrm{l}$, $0.1 \mathrm{mg} \mathrm{ml}^{-1}$ ) for $5 \mathrm{~min}$ at $65^{\circ} \mathrm{C}$ to get the template for the first PCR applications. The procedure of singlestrand conformation polymorphism analysis (SSCP) was performed according to Schwieger and Tebbe (1998). Fungal and Trichoderma communities were analysed using the internal transcribed spacer region (ITS) primer pair ITS1f/ITS4r (White et al., 1990) in a first reaction mixture of $20 \mu \mathrm{l}$ PCR Mastermix (Tag\&Go, Qbiogene), $0.5 \mu \mathrm{M}$ each primer, $2.5 \mathrm{mM} \mathrm{MgCl}{ }_{2}$ and about $20 \mathrm{ng}$ of template. Trichoderma communities were analysed using the Trichoderma primers uTf/uTrP (Hagn et al., 2007) in a first reaction mixture of $20 \mu \mathrm{l}$ PCR mix (DyNAzym EXT DNA Polymerase Kit; New England Biolabs, Ipswich, MA, USA) containing $10 \mathrm{pmol}$ of each primer, $0.2 \mathrm{mM}$ dNTPs each, $1 \times$ reaction buffer, $2.5 \mathrm{mM}$ magnesium chloride and $2.5 \mathrm{U}$ DyNAzyme Polymerase with the addition of $0.3 \%$ bovine serum albumin and 5\% dimethyl sulphoxide (Sigma Aldrich, Steinheim, Germany) and about $20 \mathrm{ng}$ template. To obtain genetic fingerprints of fungal as well as Trichoderma communities, a nested PCR was performed. In the second PCR, the fungalspecific primer pair ITS1f/ITS2rP (White et al., 1990) and the Trichoderma-specific primer pair uTf/ITS2P, respectively, were used in a $60 \mu \mathrm{l}$ reaction mixture containing $12 \mu \mathrm{l}$ PCR Mastermix (Taq\&Go; Qbiogene, BIO101), $0.5 \mu \mathrm{M}$ of each primer, $2.5 \mathrm{mM} \mathrm{MgCl}_{2}$ and $10 \mu \mathrm{l}$ of PCR product from the first
PCR as template. The PCR products were purified by the GeneClean Turbo Kit (Qbiogene, BIO101), before a $\lambda$-exonuclease (New England Biolabs) digestion and DNA single-strand folding according to Lieber et al. (2003). The polyacrylamide gel electrophoresis was performed on a TGGE apparatus (Biometra, Göttingen, Germany) at $26^{\circ} \mathrm{C}$ and $400 \mathrm{~V}$ for $19 \mathrm{~h}$ using $9 \%$ (wt vol ${ }^{-1}$ ) acrylamide gels. Afterwards, the gels were silver-stained according to the procedure of Bassam et al. (1991).

Conspicuous DNA bands of the community patterns were eluted from the gel by suspending the gel slice in $150 \mu \mathrm{l}$ elution buffer, containing $0.5 \mathrm{M}$ ammonium acetate (Sigma, Vienna, Austria), $10 \mathrm{~mm}$ magnesium acetate tetrahydrate (Sigma), 1 mM EDTA (pH 8.0, AppliChem, Darmstadt, Germany) and $0.1 \%$ (wt vol ${ }^{-1}$ ) SDS (AppliChem), for 3 days at $4{ }^{\circ} \mathrm{C}$, following DNA ethanol precipitation, centrifugation and resuspension in $10 \mathrm{~mm}$ Tris-HCl (pH 8.0). Gel-extracted DNA was reamplified by using primer ITS1/ITS2P for fungi and uTf/ITS2P for Trichoder$\mathrm{ma}$. Fragments of the expected size were sequenced with the Applied Biosystems (Foster City, CA, USA) $3130 \times 1$ Genetic Analyser sequencer Data Collection v. 3.0, Sequencing Analysis v. 5. For phylogenetic analysis and identification of sequences from SSCP bands, the BLAST algorithm according to Altschul et al. (1997) was used. To this end, sequences were first manually inspected for the presence of signature shifts indicative of the presence of chimaeric sequences and also tested for their presence by the alignment to Bellerophon (Huber et al., 2004), and only sequences devoid of chimaeras were used for the BLAST search.

Computer-assisted cluster analysis and conformational grouping (OTUs)

Computer-assisted evaluation of fungal and Trichoderma community profiles obtained by SSCP was performed by using the GelCompar software (Applied Math, Kortrijk, Belgium). The silverstained SSCP gels were scanned using a transmitted light scanner (Epson perfection 4990 Photo, Nagano, Japan) to obtain digitized gel images. The gels were normalized, which allowed band pattern of different gels to be compared, and the background was subtracted (details at the manufacturer's manual). The Pearson's correlation index $(r)$ for each pair of lanes within a gel was calculated as a measure of similarity between the community fingerprints. Finally, cluster analysis was performed by applying the unweighted pair-group method using average linkages to the matrix of similarities obtained.

DNA fragments of same length but different base composition can be separated based on their threedimensional conformation. SSCP is based on the differences in the conformation of single-stranded DNA fragments. The electrophoretic mobility of the single-stranded DNA fragments depends on their three-dimensional conformation. Each of the amplifi- 
cation products was identified by its electrophoretic distance on SSCP gel and the number of DNA fragments. According to the distance of the bands, the SSCP gels were theoretically divided into 40 operational taxonomic units (OTUs). The presence or absence of individual amplified product DNA bands in each group was scored. The obtained matrix was used to compare data for correspondence analysis (see statistics).

\section{Quantitative PCR}

Quantitative analyses were performed according to Hagn et al. (2007) with some modifications. Briefly, plasmid standards for the quantification of environmental Trichoderma spp. DNA were prepared from a cloned Trichoderma reesei (EF070658; Grosch et al., 2006) ITS1/2 fragment ligated into a pGEMT Easy Vector System (Promega, Madison, WI, USA). Amplification of extracted DNA from soil as well as from standards was carried out with an ABI 3700 Real Time PCR System. Reaction components per $20 \mu \mathrm{l}$ included $1 \mu \mathrm{l}$ of DNA, $5 \mu \mathrm{l}$ qPCR Power SYBR Green PCR Master Mix (Applied Biosystems, Foster City, CI, USA) and 3 pmol of each primer. The cycler conditions were as follows: initial $95{ }^{\circ} \mathrm{C}$ for $10 \mathrm{~min}$ followed by 30 cycles of $95^{\circ} \mathrm{C}$ for $30 \mathrm{~s}$, $60{ }^{\circ} \mathrm{C}$ for $1 \mathrm{~min}$ and detection. Each standard, control and sample was prepared in triplicates and in serial dilutions for the soil. Cycling, data collection and calculation were performed by the ABI 3700 Software according to the manufacturer's instructions. After quantification, the samples were analysed by melting curve calculation and agarose gel electrophoresis for quality control of the PCR.

\section{Isolation and characterization of fungi and}

Trichoderma

The soil dilution plate method was used for isolation of Trichoderma. Approximately $100 \mu \mathrm{g}$ of soil was mixed with $0.85 \%$ sterile $\mathrm{NaCl}$ and spread on 90-mm diameter petri plates containing Trichoderma selective medium (TSM; Smith et al., 1990), on potato dextrose agar (PDA; Merck \& Co., Whitehouse Station, NJ, USA) amended with $100 \mu \mathrm{g} \mathrm{ml}^{-1}$ streptomycin and tetracycline, respectively, and on TSMC (Elad and Chet, 1983). Plates were incubated at $25{ }^{\circ} \mathrm{C}$ with daily light conditions. Two plates per suspension were prepared, giving six plates per substrate (TSM, TSMC or PDA). After 7 days, colony-forming fungi were counted to calculate the means of colonies ( $\log _{10}$ colony-forming unit (CFU)) based on fresh weight, and all colonies resembling Trichoderma were transferred to plates containing PDA and incubated as above. Trichoderma colonies were subsequentially subcultured using singlespore technique and stored at $4{ }^{\circ} \mathrm{C}$ until DNA extraction. All isolates described in this study are conserved as plugs in liquid storage medium containing glycerol (final concentration 15\%) in the strain collection SCAM (strain collection for antagonistic microorganisms) at the Graz University of Technology (Austria).

All strains were characterized by their BOX fingerprint (Rademaker and De Bruijn, 1997) using the BOXA1R primer (5'-CTACGGCAAGGCGACGCT GACG-3'). The variability of BOX-PCR patterns was assessed by fingerprinting five strains in three independent experiments. Computer-assisted evaluation of Trichoderma community profiles obtained by BOX-PCR was performed by using the GelCompar program. Cluster analysis was performed with the unweighted pair-group method with arithmetic average algorithm.

Species identification

To identify Trichoderma isolates at the species level, a fragment of the nuclear rRNA comprising ITS1 and -2 and the 5.8S rRNA gene were amplified and sequenced as described earlier (Druzhinina et al., 2005). In addition, the fourth large intron of the translation elongation factor 1- $\alpha$ (tef1) gene was also amplified if necessary as described by Druzhinina et al. (2004). Automated sequencing was performed with an ABI Prism 3100 DNA Sequencer (Applied Biosystems, Norwalk, CT, USA) at the sequencing core facility CRIBI-Bio Molecular Research at the University of Padova, Italy. ITS1 and -2 sequences were subjected to analysis by TrichOKEY (http:// www.isth.info/tools/molkey/index.php; Druzhinina et al., 2005). In ambiguous cases, usually common for section Trichoderma, the result was re-checked by analysis of the large intron of tef1 gene sequence using sequence similarity search against a database of type sequences implemented in TrichoBLAST (www.isth.info/tools/blast; Kopchinskiy et al., 2005). For analysis of unusual ITS1 and -2 or tef1 alleles, sequences were automatically aligned with GeneDoc 2.6.002, manually edited and inspected by eye. Potentially unique alleles were then confirmed by sequence similarity search against NCBI GenBank and a database of fungal strains of Vienna University of Technology that currently contains more than 2700 Hypocrea/Trichoderma strains with more than 3300 sequences. A haplotype was considered to be unique if at least one allele (ITS1 and -2 or tef1) did not occur in any other strain isolated outside of Tenerife.

Screening selected Trichoderma isolates for antagonistic potential to plant pathogens

The in vitro inhibition of Botrytis cinerea Pers., Guignardia bidwellii (Ellis) Viala \& Ravaz, Rhizoctonia solani Kühn AG2-2IIIB and AG4, Sclerotium rolfsii Sacc., and Verticillium dahliae Kleb. V25 were determined by a dual-culture assay on PDA or Waksman agar according to Berg et al. (2002). Zones of hyperparasitism were measured after 3-7 days of incubation at nearly $25{ }^{\circ} \mathrm{C}$. 


\section{Statistics}

Correspondence analysis was used to answer the question whether a correlation exists (1) between the independently sampled fungal communities of the different sampling points and (2) between fungal communities and environmental data. For this, we used the indirect correspondence analysis (CA) and direct correspondence analysis for unimodal data of the software package Canoco 4.5 (Lepš and Šmilauer, 2003).

\section{Nucleotide sequence accession numbers}

Sequence accession numbers for sequences submitted to the NCBI nucleotide sequence database are for the fungal strains EU870043 to EU870093, and for the Trichoderma strains EU870094 to EU870135 and EU871008 to EU871036.

\section{Results}

Plant communities and habitat characterization Owing to the extraordinarily significant differences in climate and altitude on Tenerife Island, the different plant communities under investigation are extremely distinct and correspond to main climatic and oreographic vegetation zones (Table 1). Each vegetation zone is presented by one main plant community that we analysed. Data obtained for the composition of vascular plant species were highly similar for the two different sampling points within one vegetation zone. On the other hand, vascular plant data showed clear differences between the plant communities of different zones. Two communities belong to the subtropical, arid vegetation. First, the open dune vegetation (D) resembling a semidesert with scarce occurrence of succulent shrubs like Atriplex glauca var. ifniensis, Launeaea arborescens and Schizogyne serriata. Second, the succulent zone (S) rich of endemics is typical for lower altitudes in South Macaronesia, in Tenerife characterized by Euphorbia regis-jubae, Kleinia neriifolia, Lavendula canariensis, Plocama pendula and Taekolmia pinnata, for instance. The conditions of two further zones are arid as well but plant communities belong to the more temperate zone due to their occurrence in higher altitudes: the subalpine mountainous heathland (R) with Descurainia bourgaeana, Pterocephalus lasiospermus and Spartenocytisus supranubius as typical vascular plants, and the alpine desert vegetation (V) around the Pico de Teide, where the endemic Viola cheiranthifolia is found but lacking in our data set because $V$. cheiranthifolia appears only during summer time. All these communities are open vegetation types without trees. The last two communities are woodland: the semiarid Canary pine forest (P) with Pinus canariensis and Cistus species, and the Laurel wood (L) with vascular plants like Ilex canariensis, Laurus azoricus, Picconia excelsior and Dryopteris oligodonta; the only vegetation type with humid conditions. Analysing our data by direct correspondence analysis, a high correlation between the plant communities and abiotic data (precipitation, temperature and altitude) was found (data not shown).

\section{Fungal and Trichoderma communities: molecular} fingerprints

To study the diversity of the whole fungal communities, all samples were characterized by the molecular fingerprint using ITS-PCR SSCP. For all samples, between 20 and 40 bands for the total fungal (Figures $2 \mathrm{a}$ and $\mathrm{b}$ ) and between one and six bands for the Trichoderma-specific community (Supplementary Figure S1) were obtained. All patterns demonstrated a high diversity by expressing different amounts and intensities of fungal bands in all three replicates. However, the statistical analysis using GelCompar resulted in vegetation zone-specific groups (data not shown). For universal as well as group-specific community patterns, dominant and unique bands were detectable and sequenced for identification (see paragraph below). Furthermore, GelCompar bands were grouped and numbered into OTUs to analyse the diversity of fungal communities on molecular basis as well as their relationship to plant communities and environmental factors.

Correspondence analysis of fungal communities and environmental factors

Indirect correspondence analysis based on the OTUs of fungal species can show the coherence and similarity of the different samples indicated by crowding points (surrounded by ellipsoids) at a CA biplot. The analysis resulted in surprisingly clear patterns (Figure 3). All six samples (three replicates of two sampling points) of the same plant community clustered together in each case except for the desert and costal dune vegetation (D). The Laurel wood (L) is the most extraordinary and only humid ecosystem in the Macaronesian archipelago. Its fungal community showed the same unique pattern, correlated with precipitation at the second axis. These samples are the most different ones within the whole data set. The samples of semiarid and arid zones are arranged along the first axis. It is correlated with altitude as well as temperature, which itself is nearly a reciprocal value of altitude. Along this axis, the fungal communities are arranged on a gradient from high to low temperature: desert (D), pine forest (P), succulent zone (S), subalpine (R) and alpine vegetation (V); the types $\mathrm{R}$ and $\mathrm{V}$ right from the centre are characterized by an increasing occurrence of frost. According to this gradient of temperature, the situation of $\mathrm{P}$ between $\mathrm{D}$ and $\mathrm{S}$ is unexpected; it would be expected between $S$ and $R$.

The direct gradient analysis of Figure 4 shows the relationship of the samples and the response of the 
OTUs with regard to the environmental factors. The picture is clearer than in Figure 3; the P-characterizing OTUs are between $\mathrm{S}$ and $\mathrm{R}$ and have a correspondence to $\mathrm{L}$, which is a woody habitat as well. In the temperature-determined 'semiarid line' $\mathrm{D}-\mathrm{S}-\mathrm{P}-\mathrm{R}-\mathrm{V}$, the $\mathrm{P}$ units are positively and the $\mathrm{D}$ units are negatively influenced by precipitation, showing that these species are more adapted to moist or dry soil condition, respectively.

\section{Identification of fungal species}

Altogether, 53 fungal clones were cut out from SSCP gels (Figure 2), sequenced and compared with sequences deposited in GenBank. Dominant and unique bands from SSCP gels, and outstanding OTUs resulting from corresponding analysis (Figure 4) were selected. Surprisingly, with two exceptions, all sequences were designated to
Basidiomycota (Table 2). Many sequences closely matched with sequences from mycorrhizal fungi or uncultured strains. However, the majority of isolates had a very low index of similarity to known species or other strains in the databank. There are several isolates that could be identified on genus level; they belong to Cryptococcus, Hebeloma and Inocybe. Species of the Cryptococcus genus occurred ubiquitously, mainly in the vegetation zone Laurisilva (L), mountain heathland (R) and on Pico de Teide (V). They were found especially in high altitudes; in R, for example C. aerius (ITS9, -37 and -41 ), $C$. bhutanensis (ITS36 and -40) and C. phenolicus (ITS35 and -38), and in V, for example C. albidus (ITS46 and -50), C. antarcticus (ITS52), C. friedmannii (ITS49) and C. vishniacii (ITS47). C. podzolicus (ITS137, OTU35) was found only in Laurel wood (L). According to the results of our correspondence analysis, the latter was found to be

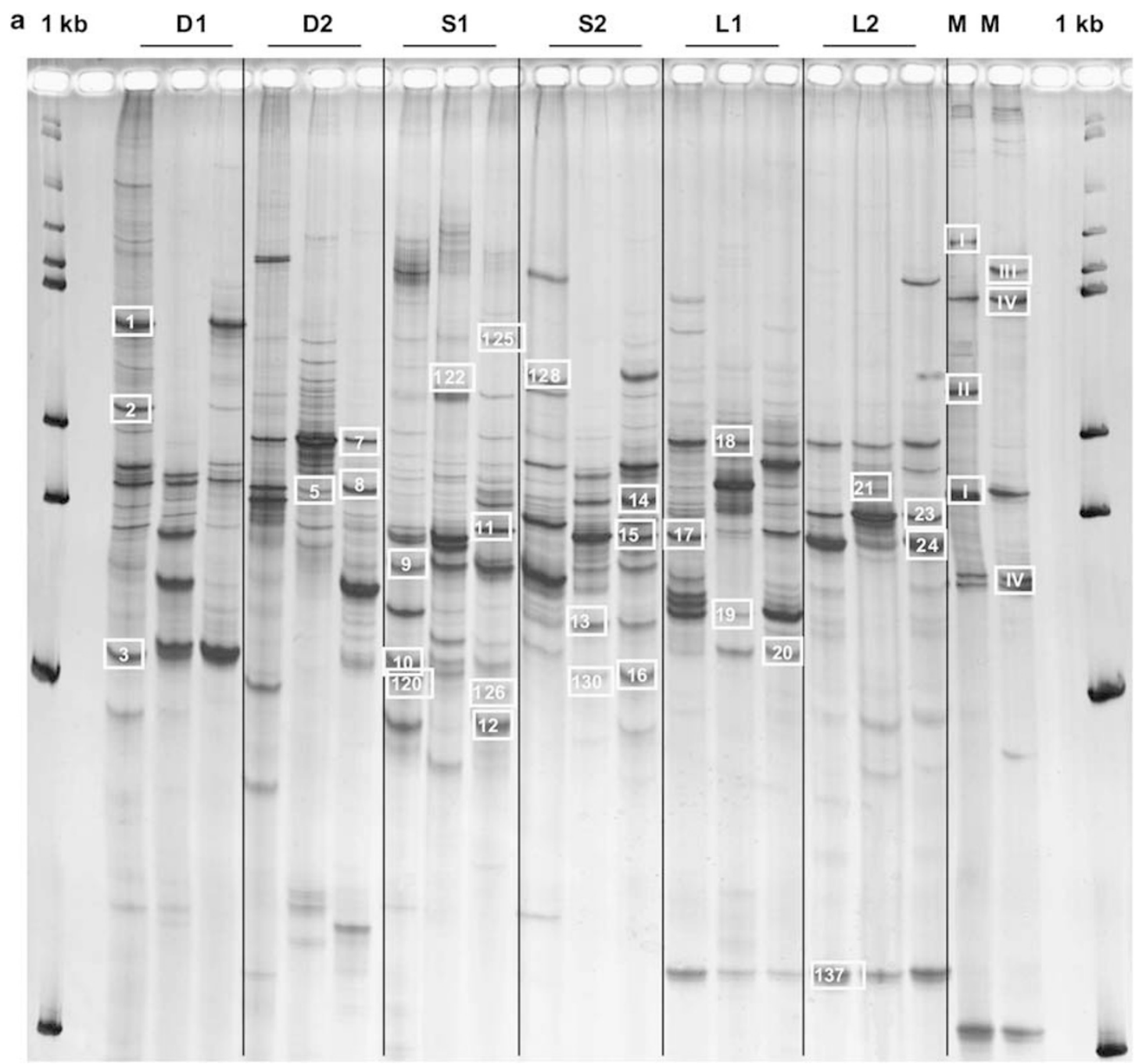

Figure 2 SSCP profiles showing the fungal communities from 13 different sampling locations in Tenerife (a) D1, D2, S1, S2, L1, L2 and (b) P1, P2, R1, R2, V1, V2 obtained using ITS1 and ITS4 primers. Lane marked M contains PCR products from pure fungal cultures: $\mathrm{I}=$ Rhizoctonia solani AG2-2IIIB, II = Trichoderma gamsii AT1-2-4, III = Verticillium dahliae V25, IV =T. cerinum G1/9 and T. viride $\mathrm{G} 3 / 2$, and $\mathrm{V}=T$. cerinum G1/9. White framed bands were excised for identification by sequencing (for results see Table 4). ITS, internal transcribed spacer region; SSCP, single-strand conformation polymorphism. 


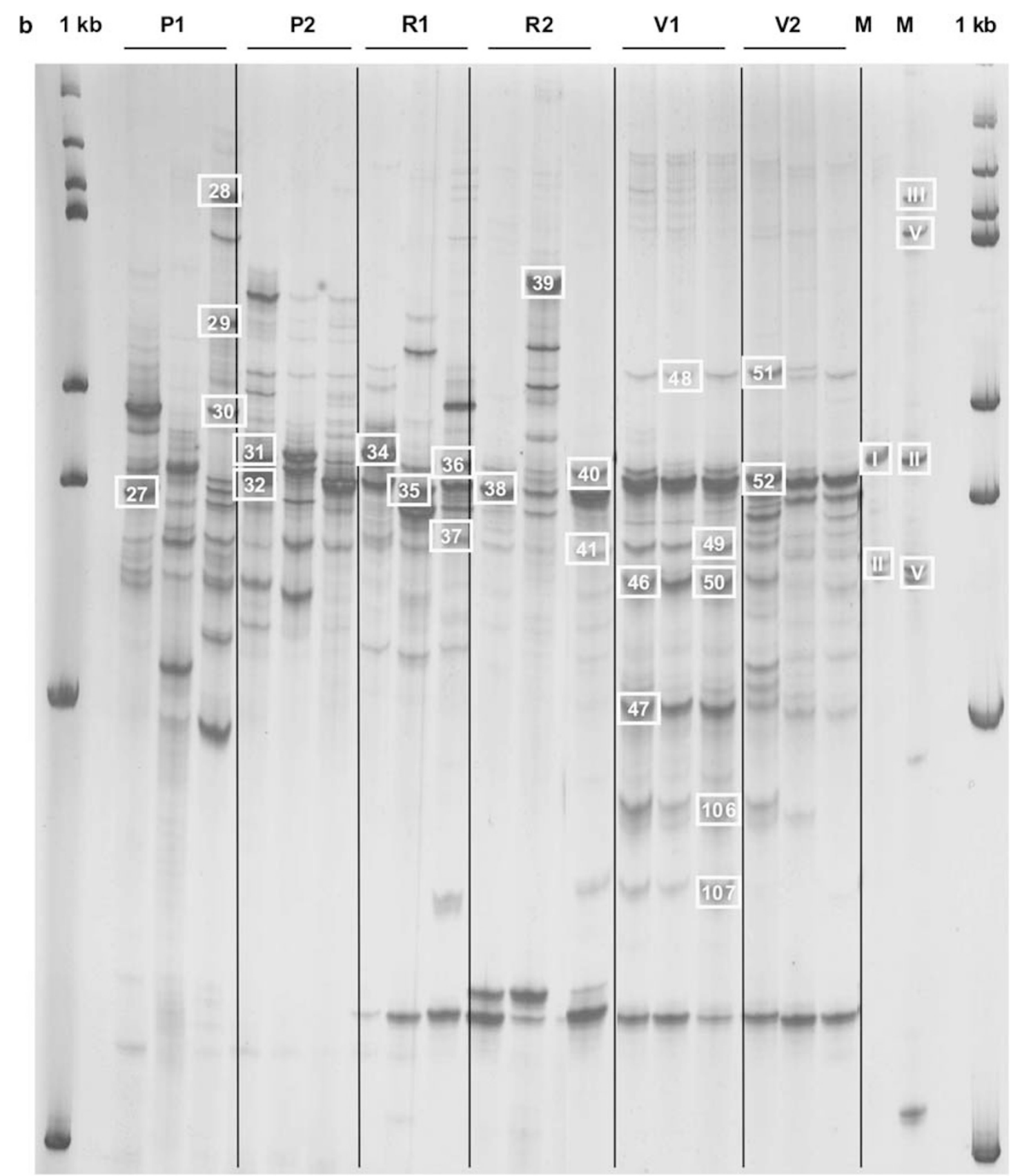

Figure 2 Continued.

specific for this vegetation zone. Other specific species were Hebeloma cistophilum (ITS29) in the Canary pine forest (P) and Noahidea sebacea (ITS107) on Pico de Teide (V). Other dominant bands were identified as Rhizoctonia spp. (ITS1, -3, -14 and -20), especially in the desert zone (D). In the succulent zone (S), mainly uncultured isolates were identified. In contrast, species of OTU groups 12, 13, 15 and 17 showed a ubiquitous behaviour.

In addition, 42 clones from the Trichoderma were sequenced (Table 3). Although the fragments allowed only the sequencing of a part of ITS1, and thus clear diagnostic sequences were not obtained, all but one clone were safely identified as Trichoderma/Hypocrea, section Trichoderma and section Pachybasium. The analysis revealed a low diversity of Trichoderma species. Yet because of hallmark areas within the sequences, three isolates could be identified at the species level ( $T$. stromaticum, T. spirale and $H$. cremea). The majority of isolates (29) exhibited an allele indicative of either T. harzianum or T. tomentosum. One isolate (TR 13) exhibited a new allele with affinity to the $H$. lixii/catoptron clade. Five isolates belonged to section Trichoderma and could not be identified closer. Interestingly, according to correspondence 


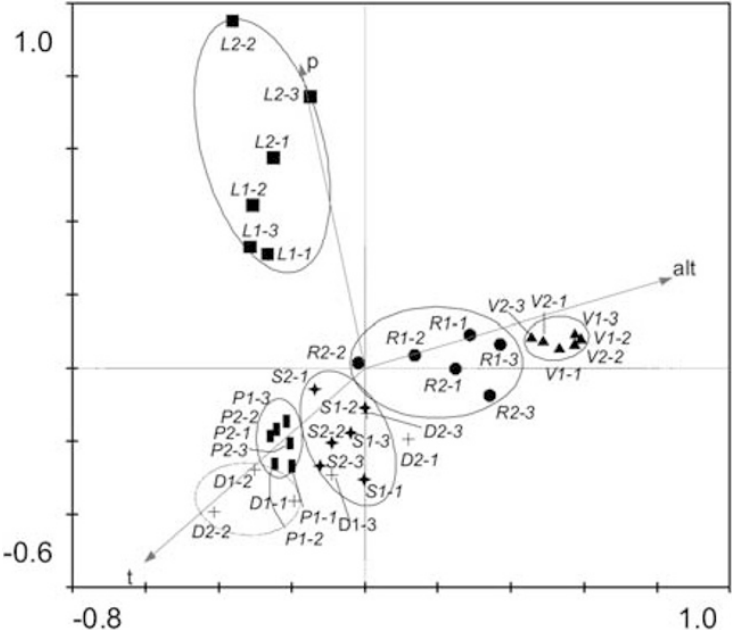

Figure 3 Correspondence analysis (indirect unimodal gradient analysis, interspecies distances, biplot scaling) of sampling sites based on operational taxonomic units of fungi community data. Eigenvalues of first and second axes are 0.24 and 0.21 , respectively; sum of all eigenvalues is 1.63. The environmental data are post hoc given as Supplementary Data. Ellipsoids show the centre of the vegetation type. $\mathrm{T}=$ temperature, $\mathrm{p}=$ precipitation, alt $=$ altitude .

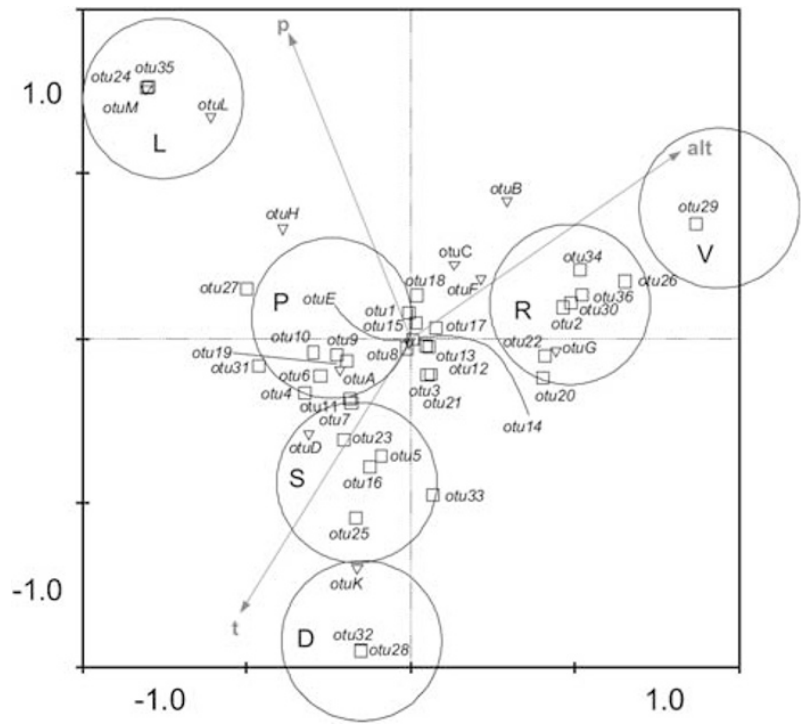

Figure 4 Canocial correspondence analysis triplot (direct unimodal gradient analysis) of operational taxonomic units (OTUs) Squares (labelled with figures) show the units from ITS data and triangles (labelled with letters) the units from Trichoderma data set. Circles indicate the location of the sampling sites. Eigenvalues of first and second axes are 0.21 and 0.17 , respectively; sum of all eigenvalues is 1.63. Environmental data are predetermined. $\mathrm{T}=$ temperature, $\mathrm{p}=$ precipitation, alt $=$ altitude. ITS, internal transcribed spacer region.

analysis, $T$. viride was found to be specific for the Laurel wood (L).

Fungal abundances, isolation and characterization of Trichoderma strains

From all sampling points, fungal as well as Trichoderma strains were isolated on different media. Altogether, CFU counts on synthetic lownutrient agar (SNA) were in the range of $\log _{10} 3.95$ and 6.97 CFU per g soil fresh weight (sfw) (average 5.41). The CFU numbers determined on PDA were slightly but not significantly higher and ranged from $\log _{10} 4.62$ to $7.04 \mathrm{CFU}$ per g sfw (average 6.55). Although no statistically significant differences were observed between the sampling points, especially in the desert zone (D) and in Teide region (V), low fungal abundances were found. Trichoderma strains were isolated on two different selective media TSM and TSCM (Smith et al., 1990; Elad and Chet, 1983) but on both media strains belonging to other fungal genera were grown. From all vegetation zones, Trichoderma colonies could be isolated. In general, on TSM, lower averages were found $\left(\log _{10} 3.97 \mathrm{CFU}\right.$ per $g$ sfw) than on TSCM ( $\log _{10} 5.69$ CFU per g sfw). Again, no statistically significant differences between the sampling points were found.

As a standard for absolute quantification, a cloned ITS1/2 fragment of an environmental $T$. reesei sequence was used in 10-fold dilutions from $10^{5}$ to $10^{2}$. Calculation of the standard curve showed an $r^{2}$ of 0.94 for the real-time PCR (data not shown). Sample curves crossed the threshold at a $C_{\mathrm{t}}$ value of 17-36 resulting in a mean copy number of $\log _{10} 4.7-8.4 \mathrm{CFU}$ per g sfw. Again, in all samples, Trichoderma DNA was found; the abundances were similar to each other and no statistically significant effect could be measured.

Owing to poor identification of Trichoderma found with direct clone sequencing, Trichoderma strains isolated from the different sampling points were characterized according to an established barcoding procedure (Druzhinina et al., 2005). A combination of ITS1/2 and tef1 sequencing identified 22 representative isolates as T. harzianum (13), T. spirale (1), T. cf. tomentosum (1), T. gamsii (3), T. viridescens (1), T. viride (1) and T. 'viride Ve' (2) (Table 4). The latter represents an as-yetundescribed phylogenetic species from the $H$. rufa clade that is so far known only from countries of the Pacific rim (Jaklitsch et al., 2006). The genotypic diversity of these Trichoderma strains was also investigated by BOX fingerprints, which revealed a higher intraspecific diversity and zonespecific genotypes. Three different molecular patterns were found for T. harzianum strains isolated from three different locations (Supplementary Figure S2). In addition, two different genotypes of T. gamsii were found, one was originated from Laurisilva (L) and the other one from the succulent zone (S)

All strains were tested for their in vitro antagonism towards various plant pathogens. The selected Trichoderma isolates were screened for their antagonistic ability to suppress the growth of $B$. cinerea, $G$. bidwellii, $R$. solani AG2-2IIIB and AG4, S. rolfsii, and $V$. dahliae. Interestingly, all of them showed an extremely high antagonistic activity. 
Table 2 Identification and taxonomic classification of fungal DNA bands separated by SSCP from different sampling locations in Tenerife Island

\begin{tabular}{|c|c|c|c|c|c|c|}
\hline OTU & Location $^{\mathrm{a}}$ & $\begin{array}{l}\text { ITS } \\
\text { band }^{\mathrm{b}}\end{array}$ & Closest NCBI database match & Accession no. & $S I^{\mathrm{c}}$ & $\begin{array}{l}\text { Taxonomic } \\
\text { grouping }\end{array}$ \\
\hline OTU4 & D1 & ITS1 & Rhizoctonia sp. & AF200520.1 & 84 & Basidiomycota \\
\hline OTU8 & D1 & ITS2 & Tulostoma kotlabae voucher MJ6623 & DQ112629.1 & 92 & Basidiomycota \\
\hline OTU21 & D1 & ITS3 & Thanatephorus sp. CBS 320.84 & DQ278949.1 & 84 & Basidiomycota \\
\hline OTU13 & D2 & ITS5 & Basidiomycete from a bamboo (Arundinaria gigantea) & U65619.1 & 84,85 & Basidiomycota \\
\hline OTU10 & D2 & ITS7 & Uncultured soil fungus clone $53-1$ & DQ421097.1 & 89 & Fungus \\
\hline OTU13 & D2 & ITS8 & Polyporus ciliatus & AB070882.1 & 87 & Basidiomycota \\
\hline OTU5 & L1 & ITS17 & Uncultured fungus clone L5_OTU39 & EF434028.1 & 90 & Fungus \\
\hline OTU10 & L1 & ITS18 & Ganoderma australe & AY884180.1 & 94 & Basidiomycota \\
\hline OTU19 & L1 & ITS19 & Entoloma bloxamii & EF530938.1 & 83 & Basidiomycota \\
\hline OTU21 & L1 & ITS20 & Rhizoctonia sp. 3-4Ll20-5p & AM040889.1 & 87 & Basidiomycota \\
\hline OTU12 & L2 & ITS21 & Hygrocybe conica & AY854074.1 & 93 & Basidiomycota \\
\hline OTU14 & L2 & ITS23 & Hygrocybe conica isolate AFTOL-ID 729 & AY854074.1 & 96 & Basidiomycota \\
\hline OTU15 & L2 & ITS24 & Marasmius sp. NC-8330/1 & AY456352.1 & 91 & Basidiomycota \\
\hline OTU35 & L2 & ITS137 & Cryptococcus podzolicus & AF444321.1 & 98 & Basidiomycota \\
\hline OTU13 & $\mathrm{P} 1$ & ITS27 & Mallocybe dulcamara isolate AFTOL-ID 482 & DQ221106.1 & 81 & Basidiomycota \\
\hline OTU1 & $\mathrm{P} 1$ & ITS28 & Hebeloma cistophilum & DQ007992.1 & 98 & Basidiomycota \\
\hline OTU6 & P1 & ITS29 & Hebeloma cistophilum voucher GLM 62250 & DQ007993.1 & 98 & Basidiomycota \\
\hline OTU10 & $\mathrm{P} 1$ & ITS30 & Inocybe nitidiuscula & AM882911.1 & 97 & Basidiomycota \\
\hline OTU12 & $\mathrm{P} 2$ & ITS31 & Uncultured ectomycorrhiza (Inocybe) isolate UBCOCS196F & EF218776.1 & 94 & Basidiomycota \\
\hline OTU13 & $\mathrm{P} 2$ & ITS32 & Inocybe cf. glabripes & AJ889952.1 & 90 & Basidiomycota \\
\hline OTU12 & R1 & ITS34 & Polyporus ciliatus & АВ070882.1 & 87 & Basidiomycota \\
\hline OTU13 & R1 & ITS35 & Cryptococcus phenolicus & AF444351.1 & 98 & Basidiomycota \\
\hline OTU12 & R1 & ITS36 & Cryptococcus bhutanensis & EU266557.1 & 99 & Basidiomycota \\
\hline OTU15 & R1 & ITS37 & Cryptococcus aerius & AF145324.1 & 97 & Basidiomycota \\
\hline OTU13 & $\mathrm{R} 2$ & ITS38 & Cryptococcus phenolicus strain CBS 8682 & AF444351.1 & 96 & Basidiomycota \\
\hline OTU5 & R2 & ITS39 & Trechispora alnicola isolate AFTOL-ID 665 & DQ411529.1 & 77 & Basidiomycota \\
\hline OTU12 & $\mathrm{R} 2$ & ITS40 & Cryptococcus bhutanensis strain CBS6294 & AF145317.1 & 97 & Basidiomycota \\
\hline OTU16 & R2 & ITS41 & Cryptococcus aerius & AF145324.1 & 99 & Basidiomycota \\
\hline OTU16 & $\mathrm{S} 1$ & ITS9 & Cryptococcus aerius strain CBS155 & AF145324.1 & 97 & Basidiomycota \\
\hline OTU21 & $\mathrm{S} 1$ & ITS10 & Uncultured soil basidiomycete clone B4 & DQ672292.1 & 91 & Basidiomycota \\
\hline OTU14 & S1 & ITS11 & Nolanea sericea & AF357021.2 & 83 & Basidiomycota \\
\hline OTU25 & $\mathrm{S} 1$ & ITS12 & Uncultured soil basidiomycete. & AY969789.1 & 88 & Basidiomycota \\
\hline OTU22 & $\mathrm{S} 1$ & ITS120 & Uncultured soil basidiomycete & DQ672292.1 & 90 & Basidiomycota \\
\hline OTU8 & $\mathrm{S} 1$ & ITS122 & Uncultured soil basidiomycete & DQ̄672292.1 & 89 & Basidiomycota \\
\hline OTU5 & $\mathrm{S} 1$ & ITS125 & Uncultured basidiomycete & EU003034.1 & 73 & Basidiomycota \\
\hline OTU23 & S1 & ITS126 & Uncultured endophytic fungus & EF505775.1 & 86 & Fungus \\
\hline OTU19 & $\mathrm{S} 2$ & ITS13 & Uncultured Auriculariales & EF619638.1 & 93 & Basidiomycota \\
\hline OTU13 & $\mathrm{S} 2$ & ITS14 & Rhizoctonia sp. 3-4Ll20-5p & AM040889.1 & 84 & Basidiomycota \\
\hline OTU15 & $\mathrm{S} 2$ & ITS15 & Psilocybe sp. & DQ002870.1 & 77 & Basidiomycota \\
\hline OTU22 & $\mathrm{S} 2$ & ITS16 & Uncultured basidiomycete isolate dfmo0724_065 & AY969789.1 & 80 & Basidiomycota \\
\hline OTU7 & $\mathrm{S} 2$ & ITS128 & Uncultured fungus & DQ093748.1 & 96 & Fungus \\
\hline OTU22 & $\mathrm{S} 2$ & ITS130 & Sphaerobolus sp. & DQ979014.1 & 77 & Basidiomycota \\
\hline OTU17 & V1 & ITS46 & Cryptococcus albidus var. ovalis & EU266553.1 & 98 & Basidiomycota \\
\hline OTU22 & V1 & ITS47 & Cryptococcus vishniacii & DQ317364.1 & 98 & Basidiomycota \\
\hline OTU8 & V1 & ITS48 & Thelebolaceae sp. & DQ317351.1 & 100 & Ascomycota \\
\hline OTU15 & V1 & ITS49 & Cryptococcus friedmannii & DQ̄317360.1 & 92 & Basidiomycota \\
\hline OTU17 & V1 & ITS50 & Cryptococcus albidus & EU266553.1 & 99 & Basidiomycota \\
\hline OTU26 & V1 & ITS106 & Erythrobasidium clade sp. & EF060907.1 & 97 & Basidiomycota \\
\hline OTU29 & V1 & ITS107 & Naohidea sebacea & DQ911616.1 & 84 & Basidiomycota \\
\hline OTU8 & V2 & ITS51 & Thelebolaceae sp. & DQ317351.1 & 99 & Ascomycota \\
\hline OTU12 & V2 & ITS52 & Cryptococcus antarcticus & AB032670.1 & 96 & Basidiomycota \\
\hline
\end{tabular}

Abbreviation: SSCP, single-strand conformation polymorphism.

${ }^{\text {a} L e t t e r s ~ r e p r e s e n t ~ t h e ~ l o c a t i o n s ~ D 1, ~ D 2, ~ L 1, ~ L 2, ~ P 1, ~ P 2, ~ R 1, ~ R 2, ~ S 1, ~ S 2, ~ V 1 ~ a n d ~ V 2 ~(s e e ~ T a b l e ~ 1) . ~}$

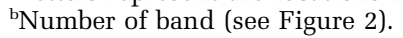

${ }^{\mathrm{c}} \mathrm{SI}$, similarity index: for isolates identified by ITS1 and ITS2 fragment (fungi) sequencing ranging from $0 \%$ to $100 \%$.

\section{Discussion}

The Canary Islands have proven to be an interesting object for studying biodiversity and diversification of species. Our model Tenerife Island is the most diverse of the Canary Islands, containing a high number of bioclimatic belts and zonal habitats in a small geographical area. In these zones, highly specific plant communities exists, and a high degree of endemic plants occurred (Francisco-Ortega et al., 2000). Furthermore, special soil types have been developed for each vegetation zone from the volcanic material due to the effects of vegetation, local weather conditions and topography 
Table 3 Identification and taxonomic classification of Trichoderma DNA bands separated by SSCP from different sampling locations in Tenerife Island

\begin{tabular}{|c|c|c|c|c|c|}
\hline OTU & Location $^{\mathrm{a}}$ & Trichoderma band ${ }^{\mathrm{b}}$ & Closest NCBI Database match and accession number & Accession no. & $S I^{c}$ \\
\hline OTUE & D2 & $\mathrm{T} 1$ & Hypocrea lixii isolate UOKT044 ${ }^{\mathrm{d}}$ & EF442082.1 & 98 \\
\hline OTUE & L1 & T5 & Hypocrea lixii isolate UOKT044 & EF442082.1 & 99 \\
\hline OTUL & L1 & T6 & Trichoderma viride isolate GJS 99-83 ${ }^{\mathrm{e}}$ & AF456921.1 & 96 \\
\hline OTUL & L1 & T64 & Trichoderma viride GJS 99-83 ${ }^{\mathrm{e}}$ & AF456.921.1 & 98 \\
\hline OTUE & L2 & $\mathrm{T} 7$ & Trichoderma spirale isolate aurim 1210 & DQ093712.1 & 98 \\
\hline OTUL & $\mathrm{L} 2$ & T8 & Trichoderma viride isolate GJS 99-83 & AF456921.1 & 96 \\
\hline OTUD & L2 & T9 & Hyросrea lixii isolate UOKT044 & EF442082.1 & 99 \\
\hline OTUL & $\mathrm{L} 2$ & T10 & Trichoderma viride isolate GJS 99-83 ${ }^{\mathrm{e}}$ & AF456921.1 & 96 \\
\hline OTUA & P1 & T11 & Hуросrea lixii isolate UOKT044 & EF442082.1 & 98 \\
\hline OTUC & P1 & $\mathrm{T} 12$ & Hypocrea lixii isolate UOKT04 & EF442082.1 & 100 \\
\hline OTUC & P1 & T13 & Hypocrea lixii strain $\mathrm{T}-18^{\mathrm{f}}$ & DQ023715.1 & 90 \\
\hline OTUH & P1 & T55 & Hypocrea lixii strain VI03698 & AM498496.1 & 99 \\
\hline OTUH & $\mathrm{P} 1$ & $\mathrm{~T} 24$ & Trichoderma hamatum isolate TUB F-617 & AF486013.1 & 75 \\
\hline OTUE & P1 & T36 & Hyросrea lixii isolate UOKT044 & EF442082.1 & 99 \\
\hline OTUA & $\mathrm{P} 2$ & T14 & Hypocrea lixii isolate UOKT044 & EF442082.1 & 98 \\
\hline OTUC & $\mathrm{P} 2$ & T15 & Hуросrea lixii isolate UOKT044 & EF442082.1 & 99 \\
\hline OTUE & P2 & T25 & Hуросrea lixii isolate UOKT044 & EF442082.1 & 98 \\
\hline OTUF & $\mathrm{P} 2$ & T26 & Hypocrea lixii isolate UOKT044 & EF442082.1 & 99 \\
\hline OTUF & R1 & T16 & Hуросrea lixii isolate UOKT044 & EF442082.1 & 99 \\
\hline OTUE & R1 & T27 & Hypocrea lixii isolate UOKT044 & EF442082.1 & 97 \\
\hline OTUE & R1 & T28 & Hуросrea lixii isolate UOKT044 & EF442082.1 & 98 \\
\hline OTUF & R1 & T73 & Trichoderma tomentosum strain UNISS $13 \mathrm{~b}-12$ & EF488143.1 & 96 \\
\hline OTUE & R2 & T29 & Hypocrea lixii isolate UOKT044 & EF442082.1 & 99 \\
\hline OTUE & R2 & T30 & Hуросrea lixii isolate UOKT044 & EF442082.1 & 99 \\
\hline OTUL & $\mathrm{R} 2$ & T31 & Trichoderma hamatum & DQ682602.1 & 97 \\
\hline OTUD & S1 & $\mathrm{T} 2$ & Trichoderma velutinum & DQ083010.1 & 99 \\
\hline OTUK & S1 & T67 & Trichoderma atroviride strain VI03932 & AM498487.1 & 98 \\
\hline OTUD & $\mathrm{S} 2$ & T3 & Hypocrea lixii isolate UOKT044 & EF442082.1 & 98 \\
\hline OTUD & S2 & $\mathrm{T} 4$ & Hуросrea lixii isolate UOKT044 & EF442082.1 & 99 \\
\hline OTUC & $\mathrm{S} 2$ & T69 & Hypocrea cremea strain GJS 91-125 & AY737760.1 & 100 \\
\hline OTUE & S2 & $\mathrm{T} 70$ & Hуросrea lixii strain VI03698 & AM498496.1 & 100 \\
\hline OTUG & V1 & T18 & Hypocrea lixii isolate UOKT044 & EF442082.1 & 99 \\
\hline OTUG & V1 & T19 & Hуросrea lixii isolate UOKT044 & EF442082.1 & 93 \\
\hline OTUE & V1 & T57 & Hуросrea lixii strain VI03698 & AM498496.1 & 100 \\
\hline OTUF & V1 & T59 & Hypocrea lixii strain VI03698 & AM498496.1 & 100 \\
\hline OTUE & V1 & T34 & Hуросrea lixii isolate UOKT044 & EF442082.1 & 97 \\
\hline OTUF & $\mathrm{V} 2$ & T20 & Hypocrea lixii isolate UOKT044 & EF442082.1 & 97 \\
\hline OTUG & $\mathrm{V} 2$ & $\mathrm{~T} 21$ & Hуросrea lixii isolate UOKT044 & EF442082.1 & 98 \\
\hline OTUF & V2 & T22 & Hypocrea lixii isolate UOKT044 & EF442082.1 & 99 \\
\hline OTUG & V2 & T23 & Hypocrea lixii isolate UOKT044 & EF442082.1 & 98 \\
\hline OTUE & V2 & T62 & Trichoderma tomentosum strain UNISS $13 \mathrm{~b}-12$ & EF488143.1 & 100 \\
\hline OTUE & $\mathrm{V} 2$ & T35 & Hуросrea lixii isolate UOKT044 & EF442082.1 & 98 \\
\hline
\end{tabular}

Abbreviation: SSCP, single-strand conformation polymorphism.

a Letters represent the locations D1, D2, L1, L2, P1, P2, R1, R2, S1, S2, V1 and V2 (see Table 1).

bNumber of band (see Supplementary S6).

'SI, similarity index: for isolates identified by uTf and ITS4 fragment (Trichoderma) sequencing ranging from $0 \%$ to $100 \%$.

${ }^{\mathrm{d}}$ T. stromaticum

'Trichoderma sp.

${ }^{\mathrm{f}}$ Hypocrea sp. according to TrichoBLAST (www.isth.info)

(Fernández Caldas et al., 1987; Hernández-Moreno et al., 2007). For example, Canarian endemic pine forests grow on two kinds of fertile soil: ancient red lands and grey clay lands with low organic material content formed in places with well-defined seasons. Heathlands are located in humid zones in young soils composed of hydrated aluminic silicates with a high level of organic material, whereas Laurisilva occurs on recent materials in places with welldefined seasons and medium-to-low organic substance levels, which lie above older soil types. Our correspondence analysis data show that each vegetation zone is characterized by specific fungal diversity data: they were very similar between both sampling sites on the island, although long distances between the sampling points mostly exist. The similarity of the results obtained by CA and direct correspondence analysis indicate a high stability of fungal communities. For Laurisilva, the famous old evergreen Laurel wood (L), which is known for its extraordinary and deviant flora, the fungal data show the highest distance within the data set. Altogether, fungal communities followed the same environmental gradients from arid to semiarid and from high to low temperature like the vascular plant vegetation.

Trichoderma is a key fungal genus in agricultural soils responsible for soil and plant health (Harman 
Table 4 Identification of Trichoderma strains isolated from sampling locations in Tenerife Island and cultivated on selective media with in vitro antagonistic potential towards various plant pathogens on potato dextrose agar

\begin{tabular}{cccc}
\hline Isolate & Location & Closest NCBI database \\
match and accession number
\end{tabular}

Botrytis Guignardia Rhizoctonia Rhizoctonia Sclerotium Verticillium cinerea bidwellii solani $\quad$ solani $A G 4$ rolfsii dahliae $V 25^{\text {a }}$

\begin{tabular}{|c|c|c|c|c|c|c|c|c|c|}
\hline $\mathrm{TR} 1^{\mathrm{b}}$ & D2 & Trichoderma harzianum & 1 & +++ & +++ & ++ & ++ & +++ & +++ \\
\hline $\mathrm{TR} 2^{\mathrm{b}}$ & D2 & Trichoderma harzianum & 1 & +++ & +++ & +++ & +++ & +++ & +++ \\
\hline $\mathrm{TR}^{\mathrm{c}}$ & D2 & Trichoderma harzianum & 1 & +++ & +++ & +++ & +++ & +++ & +++ \\
\hline $\mathrm{TR}_{4}^{\mathrm{b}}$ & D2 & Trichoderma harzianum & 1 & +++ & +++ & +++ & +++ & +++ & +++ \\
\hline $\mathrm{TR}^{\mathrm{d}}$ & D2 & Trichoderma harzianum & 1 & +++ & +++ & +++ & +++ & +++ & +++ \\
\hline $\mathrm{TR}^{\mathrm{d}}$ & D2 & Trichoderma harzianum & 1 & +++ & +++ & +++ & +++ & +++ & +++ \\
\hline $\mathrm{TR}^{\mathrm{d}}$ & D2 & Trichoderma harzianum & 1 & +++ & +++ & +++ & +++ & +++ & +++ \\
\hline $\mathrm{TR}^{\mathrm{b}}$ & $\mathrm{R} 2$ & Trichoderma chionea & 2 & +++ & +++ & +++ & +++ & +++ & +++ \\
\hline $\mathrm{TR}^{\mathrm{b}}$ & P1 & Trichoderma cf. tomentosum & 3 & +++ & +++ & +++ & +++ & +++ & +++ \\
\hline TR10 & S2 & Trichoderma gamsii & 4 & +++ & +++ & +++ & +++ & +++ & +++ \\
\hline TR11 & $\mathrm{S} 2$ & Trichoderma gamsii & 5 & +++ & +++ & +++ & +++ & +++ & +++ \\
\hline $\mathrm{TR} 12^{\mathrm{b}}$ & $\mathrm{P} 2$ & Trichoderma harzianum & 6 & +++ & +++ & +++ & +++ & +++ & +++ \\
\hline $\mathrm{TR}_{13}{ }^{\mathrm{b}}$ & L1 & Trichoderma gamsii & 7 & +++ & +++ & +++ & + & +++ & ++ \\
\hline $\mathrm{TR}_{14}^{\mathrm{b}}$ & L1 & Trichoderma chionea & 8 & - & - & - & - & - & - \\
\hline $\mathrm{TR}_{15}^{\mathrm{d}}$ & L1 & Trichoderma harzianum & 9 & +++ & +++ & +++ & +++ & +++ & +++ \\
\hline $\mathrm{TR}_{16}^{\mathrm{b}}$ & L2 & Trichoderma harzianum & 9 & +++ & +++ & +++ & +++ & +++ & +++ \\
\hline TR17 & L2 & Trichoderma harzianum & 9 & +++ & +++ & +++ & +++ & +++ & +++ \\
\hline TR18 & L2 & Trichoderma harzianum & 9 & +++ & +++ & +++ & +++ & +++ & +++ \\
\hline TR19b & L2 & Trichoderma spirale & 10 & +++ & +++ & +++ & +++ & +++ & +++ \\
\hline $\mathrm{TR} 20^{\mathrm{b}}$ & $\mathrm{L} 2$ & Trichoderma harzianum & 11 & +++ & +++ & +++ & +++ & +++ & +++ \\
\hline TR21 ${ }^{\mathrm{b}}$ & $\mathrm{L} 2$ & Hypocrea rufa & 12 & +++ & +++ & +++ & +++ & +++ & +++ \\
\hline
\end{tabular}

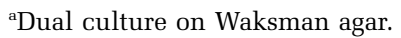

bsolated from potato dextrose medium.

'Isolated from Trichoderma selective medium.

'Isolated from modified Trichoderma selective medium.

$+0-5 \mathrm{~mm},++5-10 \mathrm{~mm},+++>10 \mathrm{~mm}$ radius of zone of hyperparasitism in dual culture assay; - no suppression.

et al., 2004; Berg et al., 2005). On Tenerife Island, in contrast, only low diversity in Trichoderma populations was found. The diversity was much lower than those reported for the rhizosphere of agricultural soils and crops; for example, as reported by Berg et al. (2005) or in South-East Asia (Kubicek et al., 2003) and South America (Druzhinina et al., 2005). All indigenous Hypocrea/Trichoderma species are cosmopolitan with an extraordinarily high antagonistic potential against fungal pathogens, and many of them are already known from many locations in Eurasia and Africa (Kubicek et al., 2003). In comparison with the whole fungal community, Trichoderma-specific communities showed a low diversity and no correlation to plant communities or abiotic factors. Therefore, this study presented different ecological and evolutionary strategies of fungi.

Our study showed that the cultivation-independent approach was able to analyse Trichoderma diversity on ITS level but was unable to unambiguously identify Trichoderma at the species level. Hagn et al. (2007) developed primers that are able to amplify an approximately 540-bp fragment comprising ITS1, 5.8S rDNA and ITS2 from all taxonomic clades of the genus Trichoderma. They are useful for quantitative PCR and fingerprint analysis but do not fit to identification systems like TrichoKey 2.0
(Druzhinina et al., 2005). Identification of strains, isolated by cultivation on plates, resulted in a pattern partially different from the cultivation-independent approach; although T. harzianum was identified as the dominant species, the two ITS1 and -2 alleles were different from those obtained from direct sequencing. One of the two alleles of the isolated strains resembled the one only found in Europe (B9b), whereas the other one (B7a) is cosmopolitan. A similar predominance of the B9b allele was recently found on the island of Sardinia (Migheli et al., 2008). Also T. spirale, T. cf. tomentosum and T. gamsii had been found to be abundant in Sardinia. In contrast to the high specificity found for the whole fungal community, Tenerife is mainly colonized by ubiquitous and widely distributed Trichoderma species and not by endemics. The high antagonistic spectrum and competitiveness of the Trichoderma isolates of Tenerife underlined the hypothesis that the Hypocrea/ Trichoderma community is suppressed by invasive strains from other continents. They can be transmitted through wind as a long distance vehicle, for example strong Passat wind known for this region, because fungal spores have been detected in the stratosphere (Muñoz et al., 2004).

The fungal communities were characterized by a high diversity and dominance of Basidiomycota, and a high degree of unidentified species. Further- 
more, many of the sequenced clones had a high similarity with clones from uncultivated, unknown fungi. However, for those that we could attribute to a genus, many of them are known to form ectomycorrhizae, an old symbiosis between fungi and plants, which help plants to obtain mineral nutrients from the soil. A similar combination of species was found by Obase et al. (2007), studying the development of ectomycorrhizae at a recently erupted volcano (Mount Usu, Japan). Another notable finding of this study was the abundance of species of the basidiomycetous yeast Cryptococcus. Isolates of Cryptococcus spp. were also detected as the major fungal population in the soil of natural areas in some other studies too (Wuczkowski and Prillinger, 2004; Vishniac, 2006; Connell et al., 2008). The predominance of Cryptococcus species in soils has been attributed to the unique polysaccharide capsules surrounding those (McFadden et al., 2006) that aid in the assimilation of nutrients from soil and thus competing with bacteria and other fungi in arid soils (Vishniac, 2006).

The functioning and stability of terrestrial ecosystems are determined by biodiversity and species composition (McCann, 2000). However, the ecological mechanisms by which biodiversity and species composition are regulated and maintained are not well understood. Interestingly, there are reports showing the effect of fungal communities on plant communities and vice versa (van der Heijden et al., 1998). Recent empirical analyses of diversity patterns of microorganisms suggest that there are biodiversity scaling rules common to all forms of life (Green and Bohannan, 2006). In our study, we could show a high correlation between plant and fungal communities and environmental factors. The fungal communities on Tenerife Island are models that follow the same rules as the plant communities. The high proportion of isolates, which could not be identified, gives an additional hint of new and endemic species. The close link between plant species and microbial community structure in the rhizosphere resulted in the development of unique fungal diversity pattern over time and showed a parallel microbial evolution.

\section{Acknowledgements}

We thank Barbara Fetz, Monika Schneider-Trampitsch, and Bettina Bauer for valuable technical assistance and Peter Remler and Sandra Abad for great help with techniques in qPCR (all Graz, Austria). The work was supported by a grant of the FWF (GB).

\section{References}

Altschul SF, Madden TL, Schaffer AA, Zhang J, Miller W, Lipman DJ. (1997). Gapped BLAST and PSI-BLAST: a new generation of protein database search programs. Nucleic Acids Res 25: 3389-3402.
Anderson IC, Cairney JWG. (2004). Diversity and ecology of soil fungal communities: increased understanding through the application of molecular techniques. Environ Microbiol 6: 769-779.

Baldwin BG, Crawforf DJ, Francisco-Ortega J, Kim SC, Sang T, Stuessy TF. (1998). Molecular phylogenetic insights on the origin and evolution of oceanic islands plants. In: Soltis PS, Soltis DE, Doyle JJ (eds). Molecular Systematics of Plants II. DNA Sequencing. Kluwer Academic Publishers: New York, pp 410-441.

Bassam BJ, Caetano-Anolles G, Gresshoff PM. (1991). Fast and sensitive silver staining of DNA in polyacrylamide gels. Anal Biochem 80: 81-84.

Berg G, Roskot N, Steidle A, Eberl L, Zock A, Smalla K. (2002). Plant-dependent genotypic and phenotypic diversity of antagonistic rhizobacteria isolated from different Verticillium host plants. Appl Environ Microbiol 68: 3328-3338.

Berg G, Zachow C, Lottmann J, Götz M, Smalla K. (2005). Impact of soil type and plant species on rhizosphereassociated fungi antagonistic to Verticillium dahliae Kleb. Appl Environ Microbiol 71: 4203-4213.

Connell L, Redman R, Craig S, Scorzetti G, Iszard M, Rodriguez R. (2008). Diversity of soil yeasts isolated from South Victoria Land, Antarctica. Microb Ecol 56: 448-459.

Druzhinina I, Chaverri P, Fallah P, Kubicek CP, Samuels GJ. (2004). Hypocrea flaviconidia, a new species with yellow conidia from Costa Rica. Stud Mycol 50: 401-407.

Druzhinina IS, Kopchinskiy AG, Komoj M, Bissett J, Szakacs G, Kubicek CP. (2005). An oligonucleotide barcode for species identification in Trichoderma and Hypocrea. Fungal Genet Biol 42: 813-828.

Elad Y, Chet I. (1983). Improved selective media for isolation of Trichoderma spp. or Fusarium spp. Phytoparasitica 11: 55-58.

Emerson BC. (2002). Evolution on oceanic islands: molecular phylogenetic approaches to understanding pattern and processes. Mol Ecol 11: 951-966.

Fernández Caldas E, Tejedor Salguero ML, Jiménez Mendoza C. (1987). Soil types in the arid zones of the Canary Islands. Catena 14: 317-324.

Fernandopullé D. (1976). Climatic characteristics of the Canary Islands. In: Kunkel G (ed). Biogeography and Ecology in the Canary Islands-Monographiae Biologica, Vol 30, Junk: The Hague, pp 185-206.

Francisco-Ortega J, Santos-Guerra A, Seung-Chul K, Crawford DJ. (2000). Plant genetic diversity in the Canary Islands: a conservation perspective. Am J Bot 87: 909-919.

Gams W. (2007). Biodiversity of soil-inhabiting fungi. Biodivers Conserv 16: 69-72.

Green J, Bohannan BJ. (2006). Spatial scaling of microbial biodiversity. Trends Ecol Evol 21: 501-507.

Grosch R, Scherwinski K, Lottmann J, Berg G. (2006). Fungal antagonists of the plant pathogen Rhizoctonia solani: selection, control efficacy and influence on the indigenous microbial community. Mycol Res 110: 1464-1474.

Hagn A, Wallisch S, Radl V, Munch JC, Schloter M. (2007). A new cultivation independent approach to detect and monitor common Trichoderma species in soils. J Microbiol Methods 69: 86-92.

Hansen A, Sunding P. (1985). Flora of Macaronesia. Checklist of vascular plants (3rd revised edition). Sommerfeltia 1: 1-167. 
Harman GE, Howell CR, Viterbo A, Chet I, Lorito M. (2004). Trichoderma species-opportunistic, avirulent plant symbionts. Nat Rev 2: 43-56.

Hernández-Moreno JM, Tejedor M, Jiménez CC. (2007). Effects of land use on soil degradation and restoration in the Canary Islands. In: Arnalds O, Óskarsson $\mathrm{H}$, Bartoli F, Buurman P, Stoops G, García-Rodeja E (eds). Soils of Volcanic Regions in Europe. Springer: Berlin Heidelberg, pp 565-579.

Huber T, Faukner G, Hugenholtz P. (2004). Bellerophon: a program to detect chimeric sequences in multiple sequence alignments. Bioinformatics 20: 2317-2319.

Huetz de Lemps A. (1969). Le climat des Iles Canaries. Ser Recher 54: 226 p Paris: Publications de la Faculté des Letres et Sciences Humaines de Paris-Sorbonne.

Humboldt A von, Bonplandt A. (1814). Relation historique du voyage aux regions equinoxiales de nouveau continent, fait en 1799-1804 par A. de Humboldt et A. Bonplandt. Vol. 1. Paris.

Jaklitsch WM, Samuels GJ, Dodd SL, Lu BS, Druzhinina IS. (2006). Hypocrea rufa/Trichoderma viride: a reassessment, and description of five closely related species with and without warted conidia. Stud Mycol 35: 135-177.

Kämmer F. (1974). Klima und Vegetation auf Tenerife, besonders im Hinblick auf den Nebelniederschlag. Scripta Geobotanica, Vol. 7. Göttingen: Goltze, pp 78S.

Kopchinskiy AG, Komon M, Kubicek CP, Druzhinina IS. (2005). TrichoBLAST: a multiloci database for Trichoderma and Hypocrea identification. Mycol Res 109: 657-660.

Kowalchuk GA. (1999). New perspectives towards analysing fungal communities in terrestrial environments. Curr Opin Biotechnol 10: 247-251.

Kubicek CP, Bissett J, Druzhinina I, Kullnig-Gradinger C, Szakacs G. (2003). Genetic and metabolic diversity of Trichoderma: a case study on South East Asian isolates. Fungal Genet Biol 38: 310-319.

Lepš J, Šmilauer P. (2003). Multivariate Analysis of Ecological Data using Canoco. Cambridge University Press: Cambridge, 282p.

Lieber A, Kiesel B, Babel W. (2003). Microbial diversity analysis of soil by SSCP fingerprinting technique using TGGE Maxi System. In: Merbach W, Hütsch BW, Augustin J (eds). Ökophysiologie des Wurzelraumes. Teubner Verlag Stuttgart, Leipzig, Wiesbaden, pp 61-65.

McCann KS. (2000). The diversity-stability debate. Nature 405: 228-233.

McFadden D, Zaragoza O, Casadevall A. (2006). The capsular dynamics of Cryptococcus neoformans. Trends Microbiol 14: 497-505.
Migheli Q, Balmas V, Komoñ-Zelazowska M, Scherm B, Fiori S, Kopchinskiy AG, Kubicek CP, Druzhinina IS (2008). Soils of a Mediterranean hot spot of biodiversity and endemism (Sardinia, Tyrrhenian Islands) are inhabited by pan-European, invasive species of Hypocrea/Trichoderma. Environ Microbiol [e-pub ahead of print 1 September 2008].

Muñoz J, Felicísimo AM, Cabezas F, Burgaz AR, Martínez I. (2004). Wind as a long-distance dispersal vehicle in the southern hemisphere. Science 304: 1144-1147.

Obase K, Tamai Y, Yajima T, Miyamoto T. (2007). Mycorrhizal associations in woody plant species at the Mt. Usu volcano, Japan. Mycorrhiza 17: 209-215.

Rademaker JLW, De Bruijn FJ. (1997). Characterization and classification of microbes by REP-PCR genomic fingerprinting and computer-assisted pattern analysis. In: Caetano-Anolle G's, Gresshoff PM (eds). DNA Markers: Protocols, Applications and Overviews. Wiley \& Sons, Inc.: New York, NY, pp 151-171.

Schwieger F, Tebbe CC. (1998). A new approach to utilize PCR-single strand conformation polymorphism for 16S rRNA gene-based microbial community analysis. Appl Environ Microbiol 64: 4870-4876.

Smith VL, Wilcox WF, Harman GE. (1990). Potential for biological control of Phytophthora root and crown rots of apple by Trichoderma and Gliocladium spp. Phythopathology 80: 880-885.

Vainio EJ, Hantula J. (2000). Direct analysis of woodinhabiting fungi using denaturing gradient gel electrophoresis of amplified ribosomal DNA. Mycol Res 104: 927-936.

Van der Heijden MGA, Klironomos JN, Ursic M, Moutoglis P, Streitwolf-Engel R, Boller T et al. (1998). Mycorrhizal fungal diversity determines plant biodiversity, ecosystem variability and productivity. Nature 396: 69-72.

Vandenkoornhuyse P, Baldauf SL, Leyval C, Straczek J, Young JP. (2002). Extensive fungal diversity in plant roots. Science 295: 2051.

Vishniac HS. (2006). A multivariate analysis of soil yeasts isolated from a latitudinal gradient. Microb Ecol 52: 90-103.

White TJ, Bruns TD, Lee S, Taylor J. (1990). Analysis of phylogenetic relationship by amplification and direct sequencing of ribosomal RNA genes. In: Innis MA, Gelfand DH, Sninsky JJ and White TJ (eds). PCR Protocols: A Guide to Methods and Applications. Academic Press: New York, pp 315-322.

Wuczkowski M, Prillinger H. (2004). Molecular identification of yeasts from soils of the alluvial forest national park along the river Danube downstream of Vienna, Austria ('Nationalpark Donauauen'). Microbiol Res 159: $263-275$.

Supplementary Information accompanies the paper on The ISME Journal website (http://www.nature.com/ ismej) 